\title{
Effect of Leaf Mold Mulch, Biochar, and Earthworms on Mycorrhizal Colonization and Yield of Asparagus Affected by Fusarium Crown and Root Rot
}

\author{
W. H. Elmer, Department of Plant Pathology and Ecology, The Connecticut Agricultural Experiment Station, New Haven 06504
}

\begin{abstract}
Elmer, W. H. 2016. Effect of leaf mold mulch, biochar, and earthworms on mycorrhizal colonization and yield of asparagus affected by Fusarium crown and root rot. Plant Dis. 100:2507-2512.

Asparagus can suffer from a crown and root rot caused by Fusarium oxysporum f. sp. asparagi and $F$. proliferatum. The disease is exacerbated when allelopathic toxins from old, rotting asparagus crowns are present in the soil. To minimize the damage from the replant problem, three strategies were examined: (i) biochar, (ii) application of earthworms (Lumbricus terrestris), and (iii) leaf mold to serve as a compost mulch and food source for earthworms. In a greenhouse, asparagus transplants were grown in soil amended with pathogen-infested asparagus residues or in nonamended soil, then both types of soil were augmented with biochar, earthworms, the combination of biochar and earthworms, or no treatment. Biochar increased arbuscular mycorrhizae (AM) colonization by $170 \%$ and reduced the incidence of root lesions by $57 \%$; however, plant weight was not affected by any of the soil treatments and there were no significant interactions among the main effects. In the absence of infested asparagus residues, biochar reduced plant growth by $32 \%$. Field plots

that had severe crown and root rot, along with two other fields that had never been planted to asparagus, were planted with asparagus crowns and treated with leaf mold mulch, earthworms plus leaf mold mulch, biochar, or biochar plus earthworms plus leaf mold mulch. Untreated plots served as the control treatment. One year later, asparagus roots sampled from plots in the two new fields had a threefold increase in AM colonization when treated with biochar compared with control plots. Biochar did not increase yield over the duration of the 2012 to 2014 harvests when compared with that of the control plots. No soil treatment affected root colonization by AM in the field where Fusarium crown and root rot was severe. Compared with the untreated control plots, the leaf mold mulch treatment applied alone increased the marketable yields in each year of harvest. Combining leaf mold with earthworms provided no added benefit. Soil amendment with leaf mulch alone may hold promise for improving asparagus production in newly planted asparagus fields.
\end{abstract}

Replanting old asparagus fields with new asparagus crowns usually results in poor, stunted stands (Grogan and Kimble 1959). Stunting is attributed to decaying crowns and roots that release allelotoxins (e.g., coumaric acid, caffeic acid, and ferulic acids) which, in turn, inhibit the growth of young transplants (Blok and Bollen 1993, 1996; Elmer 2002; Elmer et al. 1996; Yang 1982). In addition, soilborne inoculum densities of the asparagus pathogens Fusarium oxysporum f. sp. asparagi and $F$. proliferatum are usually greater in abandoned fields compared with fields never planted to asparagus (Elmer et al.1996). One strategy that has improved stand establishment of asparagus is to adopt practices that promote arbuscular mycorrhizae (AM) formation (Elmer 2002; Matsubara et al. 2001; Wacker et al. 1990b). However, AM and most soil microorganisms are inhibited by the allelochemicals present in the soil (Blok and Bollen 1996; Hartung 1987; Wacker et al. 1990a). Fusarium spp. are not affected by the toxins and can proliferate in the absence of soilborne microbial competitors (Blok and Bollen 1996; Pedersen et al. 1991). As a consequence, most asparagus growers are forced to find new land for new asparagus plantings, which can be problematic in some areas.

One possible approach for remediating this situation is to use biochar. Biochars are pyrolyzed plant wastes (Lehmann 2007) that possess tremendous absorptive properties and can improve edaphic properties of soils (Chan et al. 2007; Liang et al. 2006) and increase AM colonization of roots (Warnock et al. 2007). Matsubara et al. (2002) found increased AM colonization of asparagus when activated carbon was added to soil. In addition, biochar reduced the damaging effects of allelopathic acids on asparagus grown in the greenhouse, and increased AM colonization (Elmer and Pignatello 2011). Proportional increases in asparagus root weights along with

Corresponding author: W. H. Elmer; E-mail Wade.Elmer@ct.gov

Accepted for publication 24 July 2016.

http://dx.doi.org/10.1094/PDIS-10-15-1196-RE

(C) 2016 The American Phytopathological Society reductions in number of root lesions were observed when the biochar was added to the soil at $0,1.5$, or $3.0 \%$ (wt/wt) soil. Biochar has been instrumental in suppressing other soilborne diseases on strawberry (Fragaria $\times$ ananassa (Weston) Duchesne ex Rozier (pro sp.)), pepper (Capsicum annuum L.), and tomato (Solanum lycopersicum L) (Elad et al. 2012; Harel et al. 2012).

Applying biochar to the soil in perennial asparagus plantings presents a challenge due to the difficulty of getting biochar to the root system without damaging the established plant. Motoki et al. (2002, 2008) injected flowable, activated carbon between the rows in asparagus fields of varying ages and found that biochar stimulated growth in young fields (1 to 4 years old) but was less effective in older plantings, probably due to the more expansive root systems of the latter. Another possible means to distribute biochars to the root zones where the allelochemicals are most concentrated might be through the burrowing activity of earthworms (Edwards and Bohlen 1996; Scheu 2003). The Canadian nightcrawler (Lumbricus terrestris L) burrows to depths of more than $1 \mathrm{~m}$, opening up channels for water infiltration and, possibly, the movement of biochar to greater depths in the soil (Ehlers 1975). In previous greenhouse trials, augmenting soils with earthworms was associated with significant increases in plant weight and $>50 \%$ reduction in the incidence of root lesions caused by Fusarium spp. Concomitant with these effects was a 10- to 12-fold increase in the density of soilborne fluorescent Pseudomonas spp. and a 4-fold increase in filamentous actinomycetes (Elmer 2009). Given that earthworms have been used to remediate and restore soils contaminated with toxins (Butt et al. 1992; Rodriguez-Campos et al. 2014), it is reasonable to assume they might also aid in decomposition and detoxification of asparagus root residues. Asparagus roots can easily penetrate soil $1 \mathrm{~m}$ deep and can occupy large volumes of soil. Earthworms might also distribute biochar throughout the root zone through ingestion and release in the castings. Recently, it was demonstrated that earthworms can remove biochar from the surface of the soil (Elmer et al. 2015). However, densities of earthworms in asparagus fields are presumed to be low due to limited food reserves and the toxic asparagus residues that may be inhibitory to earthworms. 
Applying mulch to the soil surface is well documented to increase earthworm densities by providing food substrates and by creating a more suitable habitat (Edwards and Bohlen 1996; Ehlers 1975). Furthermore, studies on the effect of mulching on asparagus have shown that it reduced stress and increased yield (Nigh 1990). However, no information is available on how mulching, with and without earthworms, might affect Fusarium crown and root rot of asparagus The objectives of this study were to determine whether adding leaf mold mulch, earthworms, biochar, or a combination of the three to the soil in old asparagus fields could affect Fusarium crown and root rot and AM colonization of asparagus.

\section{Materials and Methods}

Greenhouse trials. Seeds of 'Mary Washington' asparagus were disinfested in $20 \%$ household bleach $(1.05 \% \mathrm{NaHClO})$ for $30 \mathrm{~min}$ and rinsed in tap water to minimize the incidence of seedborne Fusarium spp. Seedlings were germinated in ProMix BX potting mix (without added mycorrhizae) and fertilized every 2 weeks with 20-10-20 (N-P-K) Peter's soluble fertilizer (1.0 g/liter) (Scotts Inc.). Mineral top soil (Agway, Inc.) was autoclaved for $1 \mathrm{~h}$ at $121^{\circ} \mathrm{C}$.

Soil was prepared with biochar and earthworms and held on greenhouse benches for 2 months before being planted with asparagus. Half of the autoclaved soil was amended with dried asparagus roots and crowns that were dug from an infested field in Hamden, CT. Asparagus residues were ground in a Waring blender, passed through a 1-mm aperture-diameter sieve, and mixed into soil (10 $\mathrm{g}$ of residue per liter of soil). Residues were colonized by the Fusarium spp. as determined on Komada's selective medium (Komada 1975). The other half of the autoclaved soil was not amended and used as a control treatment (nontreated residues). The soil for each of these two soil treatments was divided in half, and one half was amended with fast pyrolysis biochar made from hardwood biomass at the rate of $3 \mathrm{~g}$ of biochar per liter of soil. This rate approximated a $10 \%$ ( $\mathrm{vol} / \mathrm{vol})$ rate. Properties of this biochar have been published (Elmer et al. 2015). The other half of the soil was not amended (untreated biochar control). Soil for each treatment combination was then dispensed into four 3.9-liter pots. Two of the pots were each augmented with 10 L. terrestris adults purchased from a fishing supply company (N.A.S. Inc.). Earthworms were stored at $10^{\circ} \mathrm{C}$ for no more than 4 weeks and rinsed three times in tap water before being used. The drainage holes on the pots had been sealed with $100-\mu \mathrm{m}$ mesh cloth to prevent escape. The other two pots were not amended with earthworms (nontreated earthworm control). Spores of a mycorrhizal inoculant (BEI Bio/Organics), which contained at least seven Glomus or Gigaspora spp., were sprinkled on the surface of all pots to ensure that AM fungi were present ( 0.05 to $0.10 \mathrm{~g} / \mathrm{pot}$ ). This was estimated to be approximately 50 to 100 spores/pot. Therefore, there were eight treatments: two asparagus residue treatments (residues and no residues) by two earthworm treatments (earthworms and no earthworms) by two biochar treatments (biochar and no biochar) (Table 1). Pots were set into Styrofoam enclosures to minimize temperature fluctuations, and the soil was irrigated with $100 \mathrm{ml}$ of tap water twice a week to maintain soil moisture. Twice a week, 1 to $2 \mathrm{~g}$ of ground, dried autoclaved alfalfa was sprinkled on the surface of each pot to provide a food source for the earthworms.

After 2 months, each pot of the two replicate pots per treatment combination was emptied, the earthworms were removed, and the soil was mixed thoroughly, dispensed into six 10-cm-diameter plastic pots, and planted with one 2-month-old asparagus seedling. Data collected from these six plants were averaged and constituted one replicate. After 12 weeks, plants were removed from the pots, roots were washed with tap water, and the fresh weights of the ferns, roots, and crown were recorded. Fern tissue was dried and reweighed. Root systems were each divided in half. One half was assayed for Fusarium crown and root rot as described below, and the other half was placed in formalin-acetic acid-alcohol fixative (FAA) (Phillips and Hayman 1970) to be assayed for AM colonization. Procedures have been described before but, briefly, feeder roots ( 1 to $2 \mathrm{~cm}$ long) were stained using the procedures of Phillips and Hayman (1970), except that lactophenol was replaced with lactoglycerol (1.0 liter of lactic acid, $72 \mathrm{ml}$ of glycerol, and $72 \mathrm{ml} \mathrm{H}_{2} \mathrm{O}$ ). The roots were examined with a dissecting microscope, and vesicles of the AM were enumerated using the procedures of Kormanik and McGraw (1982). Between 200 and 300 intersects were counted for each plant root system. Mycorrhizal colonization was expressed as a percentage of the total number of root intersects examined microscopically on which AM structures (vesicles or arbuscules) were observed. Disease severity and colonization by Fusarium spp. of feeder roots was evaluated after roots were surface disinfested in $4 \%$ household bleach $(0.21 \% \mathrm{NaHClO})$ for $4 \mathrm{~min}$. Roots were rinsed in deionized water and blotted dry on paper towels, and 1- to 4-cm-long pieces were placed on Komada's selective medium. The petri dish was then placed over a $1-\mathrm{cm}^{2}$ grid, and the total root length and diseased root length were estimated using the line-intersect method (Tennant 1975). The fraction of

Table 1. Effect of combining earthworms and biochar in soil supplemented with asparagus residues on asparagus root weight, disease severity, and root colonization by Fusarium spp. and arbuscular mycorrhizae (AM) ${ }^{\mathrm{w}}$

\begin{tabular}{|c|c|c|c|c|c|c|c|c|}
\hline \multirow[b]{2}{*}{ Residues $^{y}$} & \multirow[b]{2}{*}{ Earthworms $^{\mathrm{z}}$} & \multirow[b]{2}{*}{ Biocharz } & \multicolumn{2}{|c|}{ FRW (g) } & \multicolumn{2}{|c|}{ Diseased roots $(\%)^{x}$} & \multicolumn{2}{|c|}{$\mathbf{A M}(\%)$} \\
\hline & & & $\operatorname{Exp} 1$ & $\operatorname{Exp} 2$ & $\operatorname{Exp} 1$ & $\operatorname{Exp} 2$ & $\operatorname{Exp} 1$ & $\operatorname{Exp} 2$ \\
\hline Absent & Absent & Absent & $7.7 \mathrm{a}$ & $14.7 \mathrm{ab}$ & $2.7 \mathrm{a}$ & $2.6 \mathrm{ab}$ & $1.2 \mathrm{a}$ & $0.7 \mathrm{a}$ \\
\hline Absent & Present & Absent & $8.6 \mathrm{a}$ & $16.1 \mathrm{a}$ & $2.0 \mathrm{a}$ & $0.9 \mathrm{a}$ & $1.5 \mathrm{a}$ & $0.1 \mathrm{a}$ \\
\hline Absent & Absent & Present & $5.5 \mathrm{~b}$ & $9.8 \mathrm{~b}$ & $2.5 \mathrm{a}$ & $0.4 \mathrm{a}$ & $2.3 \mathrm{a}$ & $0.8 \mathrm{a}$ \\
\hline Absent & Present & Present & $5.0 \mathrm{~b}$ & $13.8 \mathrm{ab}$ & $1.2 \mathrm{a}$ & $3.3 \mathrm{a}$ & $4.6 \mathrm{a}$ & $1.1 \mathrm{a}$ \\
\hline Present & Absent & Absent & $6.7 \mathrm{ab}$ & $16.2 \mathrm{a}$ & $21.3 \mathrm{c}$ & $10.0 \mathrm{c}$ & $20.5 \mathrm{~b}$ & $25.0 \mathrm{~b}$ \\
\hline Present & Present & Absent & $6.6 \mathrm{ab}$ & $16.2 \mathrm{a}$ & $11.4 \mathrm{~b}$ & $6.9 \mathrm{bc}$ & $19.8 \mathrm{~b}$ & $28.3 \mathrm{~b}$ \\
\hline Present & Absent & Present & $6.5 \mathrm{ab}$ & $13.1 \mathrm{ab}$ & $8.7 \mathrm{ab}$ & $4.8 \mathrm{ab}$ & $63.0 \mathrm{c}$ & $61.0 \mathrm{c}$ \\
\hline Present & Present & Present & $6.9 \mathrm{ab}$ & $16.2 \mathrm{a}$ & $2.1 \mathrm{a}$ & $5.5 \mathrm{ab}$ & $8.0 \mathrm{ab}$ & $53.4 \mathrm{c}$ \\
\hline \multicolumn{9}{|l|}{$\operatorname{ANOVA}(P)$} \\
\hline Residues (R) & $\ldots$ & $\ldots$ & Ns & Ns & $<0.001$ & 0.050 & $<0.001$ & $<0.001$ \\
\hline Earthworms (E) & $\ldots$ & $\ldots$ & Ns & Ns & 0.040 & Ns & Ns & Ns \\
\hline Biochar (B) & $\ldots$ & $\ldots$ & $<0.001$ & Ns & 0.006 & 0.050 & 0.024 & 0.012 \\
\hline $\mathrm{R} \times \mathrm{B}$ & $\ldots$ & $\ldots$ & $<0.001$ & 0.050 & 0.015 & Ns & 0.040 & 0.030 \\
\hline $\mathrm{B} \times \mathrm{E}$ & $\ldots$ & $\ldots$ & Ns & 0.031 & $\mathrm{Ns}$ & $\mathrm{Ns}$ & 0.047 & Ns \\
\hline $\mathrm{A} \times \mathrm{B} \times \mathrm{E}$ & $\ldots$ & $\ldots$ & Ns & Ns & 0.041 & $\mathrm{Ns}$ & 0.041 & Ns \\
\hline
\end{tabular}

${ }^{w}$ Values for each of the two experiments (Exp). There were eight treatments with two replicates, and each replicate was an average of six plants (see the text for details). Values followed by differing letters are significantly different based on Tukey's honestly significant difference test at $P=0.05$. FRW $=$ fresh root weight and Ns $=$ not significant values.

x Percentage of diseased roots was estimated using the line intersect method (Tennant 1975).

y Asparagus residues consisted of dried, ground root and crown tissue applied at $10 \mathrm{~g}$ of residue per liter of soil.

${ }^{\mathrm{z}}$ Earthworms (Lumbricus terrestris) added to pots at 10 adults/pot and biochar added at $3.0 \mathrm{~g} / \mathrm{liter}$ of soil. 
intersects at which a root had a reddish lesion was also counted and used to estimate root disease severity $[\%$ root lesions $=$ (number of intersects with root lesions/total number of intersects $) \times 100$ ]. Root colonization by Fusarium spp. was also measured as another estimate of disease. Plates were incubated at room temperature for 5 days, and the number of Fusarium colonies that grew from the roots was counted and used to estimate root infection (Fusarium colonies per centimeter of feeder root). Between 1.5 and $2.0 \mathrm{~m}$ of feeder roots were sampled per plant. The experiment was repeated the following year.

Field studies. Six treatments were applied to field plots established in 2010 in three separate locations that varied by cropping history and soil type. Plots for these trials were maintained until fall 2014. The treatments were no treatment; leaf mold mulch; earthworms plus leaf mold mulch; biochar; the combination of biochar, mulch, and earthworms; and sodium chloride $(\mathrm{NaCl})$. A leaf mold mulch treatment was included to provide a food base for the earthworms and was composed of rotting leaves that had been composted for 8 months. Leaf mold compost was prepared from a local municipal leaf collection that was mixed and composted in a large piles for 2 years. $\mathrm{NaCl}$ was applied at $560 \mathrm{~kg} / \mathrm{h}$ a to reduce resident earthworm activity, and because asparagus is tolerant of relatively high soil concentrations of $\mathrm{NaCl}$ (Elmer 1992).

The first trial was done in Hamden, CT (Cheshire sandy loam, $\mathrm{pH}$ $6.5,41.406 \mathrm{~N},-72.904 \mathrm{~W}$ ) in soil that had been in asparagus for 18 years and where Fusarium crown and root rot had been severe. The field was plowed in early May 2010. Plots were each $0.68 \mathrm{~m}^{2}$. Trenches $(1.50 \mathrm{~m}$ long by $0.45 \mathrm{~m}$ wide) were dug $(0.30 \mathrm{~m}$ deep) and spaced $1.50 \mathrm{~m}$ apart for each plot. Biochar treatments were applied randomly to half of the trenches and hand mixed with the soil to achieve an approximate $1 \%$ rate $\left(2.0 \mathrm{~kg} / \mathrm{plot}, 3.0 \mathrm{~kg} / \mathrm{m}^{2}\right)$. Oneyear-old crowns of 'Jersey Giant' were purchased from Walker Plants and sorted into small (7 to $10 \mathrm{~g}$ ), medium (11 to $20 \mathrm{~g}$ ), and large crowns ( 21 to $30 \mathrm{~g}$ ). Jersey Giant has become one of the industry standards for asparagus production, and has high vigor and some tolerance to Fusarium crown and root rot (Ellison et al. 1990). Trenches were redug, and five medium crowns were set $30 \mathrm{~cm}$ apart. Crowns were covered. Two weeks later, 50 adult earthworms (L. terrestris) were released uniformly over randomly assigned replicate plots. This rate $\left(75 \mathrm{~m}^{2}\right)$ represented a high earthworm density for an agricultural soil but is considered average for a grassland soil (Xu et al. 2013). No effort was made to corral earthworms because, once they form burrows, earthworms tend not to move horizontally more than a few meters as long as food reserves are present. Nontreated border rows were placed between the treated rows. Plots receiving leaf mold received approximately 20 liters of composted leaf mold applied to the surface to provide a food source for the earthworms.

The other two field locations were established in Griswold, CT (pH 6.4, 41.56166 N, -71.875 W) and Windsor, CT (Merrimack fine loamy sand, pH 6.2, $41.849 \mathrm{~N},-72.663 \mathrm{~W})$. Plots in Griswold and Windsor had never been cropped to asparagus. Longer trenches ( $0.30 \mathrm{~m}$ deep by $0.45 \mathrm{~m}$ wide) were dug in rows $3.0 \mathrm{~m}$ long and $1.5 \mathrm{~m}$ apart and planted with 101 -year-old medium-size crowns in June 2010, as described above for the first trial. No treatments were applied until 2011 to allow 1 year for crowns to establish. Biochar $\left(4 \mathrm{~kg}\right.$ at $\left.3.0 \mathrm{~kg} / \mathrm{m}^{2}\right)$ was side dressed around each plot in June and 100 adult earthworms $\left(75 / \mathrm{m}^{2}\right)$ were applied to designated plots. Leaf mold mulch was applied to designated plots the same day. No attempt was made to recover earthworms at the end of the study because the extraction chemicals (hot mustard and formalin) would introduce toxicity issues to the host plant. Treatments were replicated five times at both sites in a randomized block design. Untreated border rows were planted between treated rows.

In all three sites, each plot was treated with 10-10-10 N-P-K fertilizer at $56 \mathrm{~kg} / \mathrm{ha}$ in July 2012. In the year of planting, weeds were removed by hand while glyphosate was applied in each of 2011 to 2014 before the spears emerged each spring at the rate of 9.35 liters/ha. Applications of metribuzin and napropamide were applied at labeled rates in each June 2011 to 2014.
Because crown vigor and AM colonization are important in the longevity of a planting, all plots in all three sites were sampled in July 2011 for AM colonization of feeder roots. Soil cores $(15 \mathrm{~cm}$ by $3 \mathrm{~cm}$ diameter) were removed approximately $15 \mathrm{~cm}$ from the crowns. Six cores, three from each side, were sampled, bulked, and taken to the greenhouse, where roots and soil were passed through 1.4-mm sieves with a gentle stream of tap water. Roots were collected with forceps from the sieves, washed again in tap water, placed in FAA, and later stained for AM, as described above. Roots collected from the Hamden site, where Fusarium crown and root rot was severe, were divided in half, and one half was assayed for lesions and colonization by Fusarium spp., as described above.

In July 2014, every plot was rated on a scale of 1 to 5 , where $1=$ vigorous, multiple stalks per crown; $2=$ slightly less dense ferns; 3 = sparse fern tissue, one to two crowns missing; $4=$ few stalks per crown, many missing crowns; and $5=$ weak, badly stunted, and sparse ferns, few crowns alive.

In 2012 to 2014, spears were harvested three times a week beginning in late April into May for 10 harvests in 2012, 12 harvests in 2013, and 15 harvests in 2014. Asparagus harvests are typically extended each year as the planting becomes more established. Spears $22 \mathrm{~cm}$ or longer in each plot were cut, counted, and weighed, then trimmed to $22 \mathrm{~cm}$ and reweighed. Because differences among the biochar and earthworm treatments were very small the first year of harvest, the accumulated yield from each replicate plot was totaled over the 3 years and subjected to analysis of variance (ANOVA).

Statistical methods. All percent disease estimates and percent AM colonization were arcsine transformed prior to analysis by ANOVA to establish homogeneity of the variances after testing for the normality of the data. Repetitions of the greenhouse experiment were analyzed for treatment-repetition interactions, and presented separately by repetition because significant interactions were detected for asparagus fresh weights $(P=0.02)$, percent root rot disease $(P=0.05)$, and AM root colonization $(P=0.02)$. Results for each field trial were analyzed as a randomized block one-way ANOVA. Treatment effects were tested as fixed variables using the SYSTAT V13 (Cranes Software International Limited) procedure for mixedmodel ANOVA, with year and replication as random effects. The Hamden site where Fusarium crown and root rot was severe was analyzed separately, whereas the Griswold and Windsor field studies were analyzed for treatment-location interaction and combined because no significant interactions effects were observed. Means were separated using Tukey's honestly significant difference test at $P=0.05$.

\section{Results}

Greenhouse studies. Significant interactions between the main effect treatments (asparagus residues, earthworms, and biochar) and the two repetitions of the greenhouse experiments were detected; therefore, results are presented individually for each repetition of the experiment (Table 1). In both experiments, the presence of asparagus residues had a significant main effect of increasing the percent diseased roots from 2.1 to $10.9 \%(P<0.001)$ and from 1.8 to $6.8 \%$ $(P=0.050)$ for experiments 1 and 2 , respectively. Asparagus residues also increased the percent root colonization by AM from 2.4 to $27.9 \%(P<0.001)$ and from 0.8 to $41.9 \%(P<0.001)$ for experiments 1 and 2, respectively. Asparagus residues had an insignificant main effect on asparagus root fresh weight (Table 1). The main effect of earthworms was only significant for the percent diseased roots in experiment $1(P=0.040$, with a decrease in diseased roots in the presence of earthworms), and was insignificant for root fresh weight or percent AM colonization of the roots (Table 1). In contrast, the biochar treatment had a significant main effect on reducing root fresh weight, but only in experiment $1(P<0.001)$. The biochar treatment decreased the percent roots diseased from 9.4 to $3.6 \%(P=0.006)$ and from 5.1 to $3.5 \%(P=0.050)$ in experiments 1 and 2 , respectively. The percent root AM colonization was increased by the biochar treatment from 10.8 to $19.5 \%(P=0.024)$ from 13.5 to $29.1 \%$ $(P=0.012)$ in experiments 1 and 2 , respectively (Table 1$)$. The earthworm treatment had no effect on AM root colonization. 
Field studies. There was no significant effect of any of treatments on AM colonization of asparagus feeder roots sampled at the field trial where Fusarium crown and root rot was severe. The percent root colonization by AM ranged from 1.4 to $10.1 \%$ across the various treatments evaluated (Table 2). The percent root lesions observed on the asparagus planted in this site was reduced by leaf mold mulch (from $52.6 \%$ in the control plots to $22.6 \%$ in the leaf mold mulch plots) and the leaf mold mulch plus biochar treatment (52.6 to $17.3 \%$, with no significant difference from this treatment compared with the leaf mold mulch alone). The percent root lesions was not reduced by the biochar treatment alone (Table 2). Similarly, when the visual, aboveground disease ratings were assessed in summer 2014, only the combination of mulch, earthworms, and biochar reduced disease ratings from 2.5 in control plots to 1.5 in plots with all three soil amendments $(P=0.05)$. The total number of spears and total marketable yield of asparagus was not affected by any of the soil treatments (Table 2).

In the two fields that did not have a history of asparagus culture, there was no significant interaction between the soil treatments and trial sites for percent AM colonization $(P=0.64)$, aboveground disease ratings $(P=0.357)$, or marketable yield $(P=0.282)$ but the main effect of site had a significant effect on aboveground disease ratings and marketable yield ( $P=0.007$ and $P<0.001$, respectively). Yields were significantly higher and aboveground disease ratings were significant lower in Windsor than Griswold. However, the main effect of soil treatments had a significant effect on AM root colonization and marketable asparagus yield $(P<0.001$ and $P=0.030$, respectively). Therefore, data from both sites were pooled (Fig. 1). Only the two biochar treatments (biochar alone or biochar combined with earthworms and leaf mold mulch) increased AM colonization by more than threefold that of the control plots; however, there was no significant difference between the two biochar treatments (i.e., biochar alone had the same effect as a combination of all three soil amendments; Fig. 1A). Compared with nontreated plots, there was a significant increase in marketable spear weights in plots treated with leaf mold mulch alone or with leaf mold mulch plus earthworms (Fig. 1B). The inclusion of earthworms with the leaf mold mulch did not increase yields compared with leaf mold mulch alone. The $\mathrm{NaCl}$ treatment, designed to reduce ambient densities of earthworms, did not have a statistically significant effect on asparagus yield or root colonization by AM. The effect of these treatments on total spear number and total untrimmed spear weights followed the same trends as the marketable yield. Spear number, untrimmed spear weight, and trimmed spear weight were greater at the Windsor trial site than at the Griswold trial site (data not shown).

\section{Discussion}

Two strategies were explored in the greenhouse and three strategies were explored in field trials in this study to reduce the allelopathic and pathological effects of old Fusarium spp.-infested asparagus residues on young asparagus transplants and crowns. In the greenhouse, it was hypothesized that the biochar would absorb the allelopathic chemicals released by old asparagus residues into the soil (Gomez-Eyles et al. 2011), and the activity of earthworms would improve root growth (Elmer 2009). Combining earthworms with biochar amendments did not produce a synergistic reaction. In general, biochar increased AM colonization and reduced the percentage of root lesions in asparagus residue-infested soils in the greenhouse trials but these ameliorating effects did not result in increased asparagus growth. Treatment of asparagus residue-infested soils with earthworms had no consistent effect on disease in the greenhouse, because the percent roots with Fusarium crown and root rot symptoms was reduced in only one of two greenhouse experiments by the addition of earthworms to the soil and, in one of the two greenhouse experiments, addition of earthworms actually reduced

\section{A}

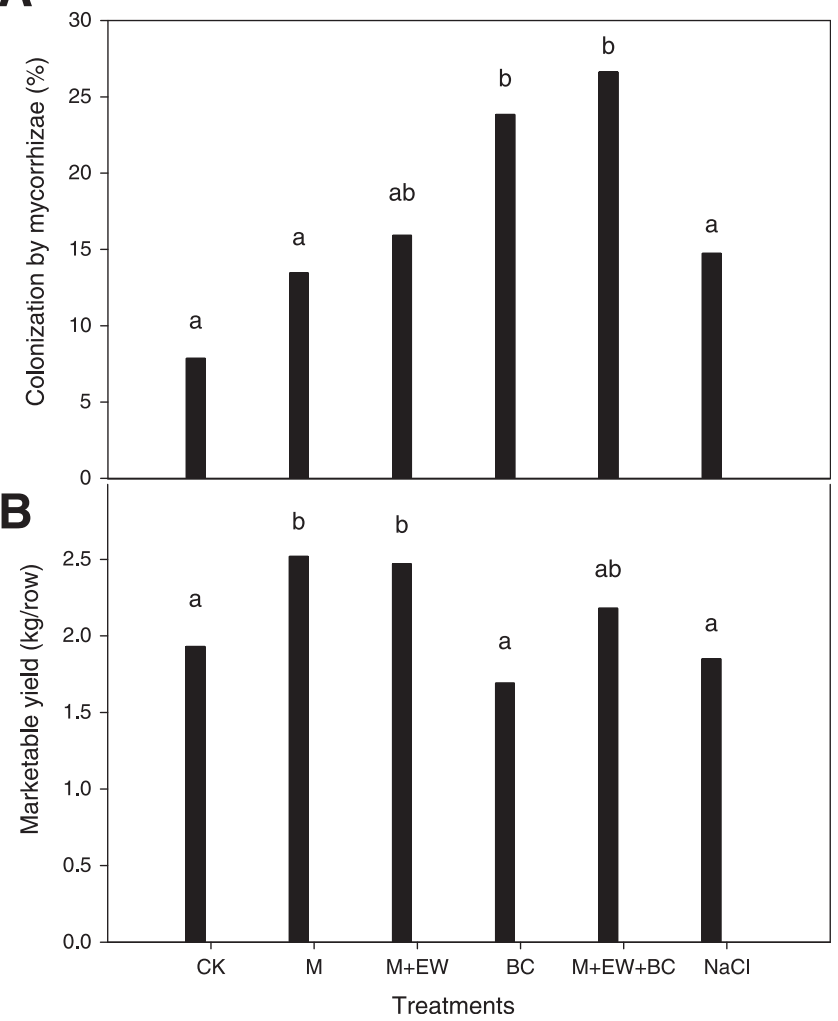

Fig. 1. The effect of amending soil with leaf mold mulch (M); leaf mold mulch plus earthworms $(\mathrm{M}+\mathrm{EW})$; biochar $(\mathrm{BC})$; the combination of leaf mold mulch, earthworms and biochar $(\mathrm{M}+\mathrm{EW}+\mathrm{BC})$; or sodium chloride $(\mathrm{NaCl})$ on the $(\mathbf{A})$ percentage of feeder roots of asparagus plants colonized by arbuscular mycorrhizae in field plots in Griswold, CT and Hamden, CT; and (B) (marketable spear yield of asparagus plants in field plot in Griswold, CT and Hamden, CT (1 kg yield/row $=2,150 \mathrm{~kg} / \mathrm{ha})$. Means were averaged over all plots in the two site $(n=$ 10); bars with different letters are significantly different based on Tukey's Honesty Significant Difference test at $P=0.05$

Table 2. Arbuscular mycorrhizae (AM) colonization, disease ratings, and accumulated marketable yield for 2012, 2013, and 2014 in Hamden, CT in a field that had a history of Fusarium crown and root rot (FCRR), with the soil then treated with combinations of leaf mold mulch, earthworms, biochar, and $\mathrm{NaCl}^{\mathrm{w}}$

\begin{tabular}{|c|c|c|c|c|c|}
\hline Treatment $^{\mathrm{x}}$ & $\operatorname{AM}(\%)$ & Diseased roots $(\%)^{\mathrm{y}}$ & Disease ratings $^{\mathrm{z}}$ & Total spear no. $(\times 1,000 / h a)$ & Total marketable yield $(\times 1,000 \mathrm{~kg} / \mathrm{ha})$ \\
\hline Control & $5.7 \mathrm{a}$ & $52.6 \mathrm{a}$ & $2.5 \mathrm{a}$ & 51 & 802 \\
\hline Mulch (M) & $3.6 \mathrm{a}$ & $22.6 \mathrm{~b}$ & $2.0 \mathrm{ab}$ & 62 & 916 \\
\hline$M+E$ & $4.0 \mathrm{a}$ & $17.3 \mathrm{~b}$ & $2.1 \mathrm{ab}$ & 52 & 781 \\
\hline Biochar (B) & $9.5 \mathrm{a}$ & $28.8 \mathrm{ab}$ & $2.2 \mathrm{ab}$ & 46 & 657 \\
\hline$M+B+E$ & $10.1 \mathrm{a}$ & $34.1 \mathrm{ab}$ & $1.5 \mathrm{~b}$ & 56 & 738 \\
\hline $\mathrm{NaCl}$ & $1.4 \mathrm{a}$ & $44.9 \mathrm{a}$ & $2.1 \mathrm{ab}$ & 55 & 789 \\
\hline
\end{tabular}

${ }^{w}$ Each values represent the mean of five plots; values within each site followed by differing letters are significantly different based on Tukey's honestly significant difference test at $P=0.05$.

${ }^{x}$ Mulch $=20$ liters applied to the surface, earthworms $(E)=75$ adults/plot, biochar added to the soil at $3.0 \mathrm{~kg} / \mathrm{m}^{2}$, and NaCl added at $500 \mathrm{~kg} / \mathrm{ha}$.

y Diseased roots determined in August 2011 using the line intersect method (Tennant 1975).

${ }^{z}$ Disease ratings made in July 2014 based on a scale of 1 to 5 , where 1 = vigorous, multiple stalks per crown; $2=$ slightly less dense ferns; $3=$ sparse fern tissue, 1 to 2 crowns missing; 4 = few stalks per crown, with many missing crowns; and $5=$ weak, badly stunted, and sparse ferns, with few crowns alive. 
the percent roots colonized by AM. In the field, the leaf mold mulch applied solely for the purpose of feeding earthworms was as effective alone at increasing asparagus yield as the combination of leaf mold mulch with earthworms.

An increase in AM root colonization following biochar amendment in the greenhouse trials and the two field trial sites with no history of asparagus production was evident. However, because the effect was not observed in the field trial site with a history of asparagus production, asparagus residues, and Fusarium crown and root rot, there is no evidence to suggest that biochar is effective at detoxifying the allelopathic chemicals released into the soil by old asparagus residues. A past study showed that biochar was effective at reducing the damaging effect of specific allelopathic toxins to asparagus (Elmer and Pignatello 2011). This effect might have enabled AM spores to germinate and colonize the young roots. However, the lack of a significant effect of biochar on AM root colonization in the field site with a long history of asparagus production showed that this effect may not always occur. It was also surprising to see no growth or yield benefits in this study because AM colonization following biochar amendment has been shown to enhance asparagus growth and suppress Fusarium crown and root rot (Arriola et al. 2000; Elmer and Pignatello 2011; Matsubara et al. 2001; Wacker et al. 1990b). The biochar used in these studies had previously been shown to promote plant growth and AM colonization of the asparagus in a greenhouse (Elmer and Pignatello 2011) but, in this study, the same biochar was not associated with improved asparagus growth, even though AM root colonization in the greenhouse trials increased. Differences in residue toxicity of fresh (Elmer and Pignatello 2011) versus dried asparagus residues (this study used the latter) may have affected the results. LeCroy et al. (2013) also reported that, in sorghum (Sorghum bicolor L.) trials, biochar reduced growth by more than $30 \%$ even though AM colonization of the roots increased from 10 to $>50 \%$. They proposed that, in well-fertilized plots treated with biochar, the AM root colonization increased to a level that may have caused an alteration in the mutualism or parasitism relationship between AM and the host, resulting in reduced biomass. Johnson et al. (1992) also reported poorer growth in corn when spore densities of AM were very high. They hypothesized that certain detrimental AM proliferated in monoculture. Another explanation for the lack of yield response with biochar may be that biochar absorbed some nutrients, such as nitrogen, and deprived the young asparagus crowns of nitrogen and other nutrients. Failure to promote a vigorous asparagus crown the first year can be very damaging to field longevity and very difficult to correct (Grogan and Kimble 1959). A readjustment of fertilization rates may have to be considered with biochar amendment. In addition, the optimal biochar rates may need refinement. Jaiswal et al. (2014) reported that higher rates of biochar increased damping-off caused by Rhizoctonia solani, and that the effect of biochars on plant growth and on plant diseases was not well correlated. Although details of the AM root colonization were not studied in those reports, a negative quadratic relationship curve was often observed in disease severity response versus biochar amendment rate, suggesting that optimal rates may need to be established for each cropping system or site.

It was also hypothesized in this study that earthworms might provide a mode of delivery of biochar by ingesting and transporting biochar deeper into the soil profile and by opening up burrows to allow biochar to be moved in the percolation water. Recently, Elmer et al. (2015) demonstrated that earthworms preferentially remove certain biochars while avoiding others. The biochar used in the current study was later found to be one that was avoided by earthworms. This may explain, in part, the lack of a significant positive effect and interaction of biochar and earthworms on asparagus growth in this study.

Other studies with earthworms found that amendment of the soil with earthworms increased plant growth and increased soil densities of beneficial microbes such as fluorescent pseudomonads and filamentous actinomycetes (Elmer 2009), and increased the yield of eggplant (Elmer and Ferrandino 2009). The findings of this study indicated that the leaf mold mulch treatment alone had as much value at increasing asparagus growth as combining the leaf mold mulch with earthworms (i.e., there was no benefit from adding earthworms to the leaf mold mulch treatment). It is not clear whether the leaf mold mulch favored an increase in resident populations of earthworms. The difficulty of accurately measuring earthworm densities in natural plantings hindered the validation of this hypothesis.

It is reported that inorganic chemicals such as $\mathrm{NaCl}$ are inhibitory to earthworms (Edwards and Bohlen 1996). $\mathrm{NaCl}$ applications are also effective at suppressing Fusarium crown and root rot on highly susceptible cultivars such as Mary Washington (Elmer 1992) but are relatively ineffective in young asparagus fields planted with the more tolerant, all-male hybrids (Elmer 1992). In this study, it was hypothesized that $\mathrm{NaCl}$ would suppress resident levels of earthworms but, because the plots that received the $\mathrm{NaCl}$ treatment did not differ from the nontreated control plots for all variables measured, the contribution of any resident earthworms, if present, appears to have been negligible.

In summary, this study provided no evidence that combining biochar and earthworm applications to the soil in fields used for asparagus replantings will reduce root disease or increase asparagus yield. On the contrary, the application of leaf mold mulch was the best treatment for enhancing yield. The underlying mechanism for why leaf mold mulching improved yield may involve, in part, an increase in resident earthworm species, but this requires validation.

\section{Acknowledgments}

I thank P. Thiel for technical assistance and R. Cecarelli, R. Durgy, and J. Preste for assistance in the field. This work was partially funded by the Connecticut Department of Agriculture Specialty Crop Block Grant and United States Department of Agriculture Hatch funds (Project 644).

\section{Literature Cited}

Arriola, L. L., Hausbeck, M. K., Rogers, J., and Safir, G. R. 2000. The effect of Trichoderma harzianum and arbuscular mycorrhizae on Fusarium root rot in asparagus. HortTechnology 10:141-144.

Blok, W. J., and Bollen, G. J. 1993. The role of autotoxins from root residues of the previous crop in the replant disease of asparagus. Neth. J. Plant Pathol. 99 (Suppl. 3):29-40.

Blok, W. J., and Bollen, G. J. 1996. Interactions of asparagus root tissue with soil microorganisms as a factor in early decline of asparagus. Plant Pathol. 45:809-822.

Butt, K. R., Frederickson, J., and Morris, R. M. 1992. The intensive production of Lumbricus terrestris L. for soil amelioration. Soil Biol. Biochem. 24:1321-1325.

Chan, K. Y., Van Zwieten, L., Meszaros, I., Downie, A., and Joseph, S. 2007. Agronomic values of greenwaste biochar as a soil amendment. Soil Res. 45: 629-634.

Edwards, C. A., and Bohlen, P. J. 1996. Biology and Ecology of Earthworms, 3rd ed. Chapman \& Hall, London.

Ehlers, W. 1975. Observations on earthworm channels and infiltration on tilled and untilled loess soil. Soil Sci. 119:242-249.

Elad, Y., Cytryn, E., Meller Harel, Y., Lew, B., and Grabar, E. R. 2012. The biochar effect: Plant resistance to biotic stresses. Phytopathol. Mediterr. 50: 335-349.

Ellison, J. H., Garrison, S. A., and Kinelski, J. L. 1990. Male asparagus hybrids: Jersey Gem, Jersey General, Jersey King, Jersey Knight and Jersey Titan. HortScience 25:816-817.

Elmer, W. H. 1992. Suppression of Fusarium crown and root rot of asparagus with sodium chloride. Phytopathology 82:97-104.

Elmer, W. H. 2002. Influence of formononetin and $\mathrm{NaCl}$ on mycorrhizal colonization and Fusarium crown and root rot of asparagus. Plant Dis. 86:1318-1324.

Elmer, W. H. 2009. Influence of earthworm activity on soil microbes and soilborne diseases of vegetables. Plant Dis. 93:175-179.

Elmer, W. H., and Ferrandino, F. J. 2009. Suppression of Verticillium wilt of eggplant by earthworms. Plant Dis. 93:485-489.

Elmer, W. H., Johnson, D. A., and Mink, G. I. 1996. Epidemiology and management of the diseases causal to asparagus decline. Plant Dis. 80:117-125.

Elmer, W. H., Lattao, C. V., and Pignatello, J. J. 2015. Active removal of biochar by earthworms (Lumbricus terrestris L). Pedobiologia (Jena) 58:1-6.

Elmer, W. H., and Pignatello, J. J. 2011. Effect of biochar amendments on mycorrhizal associations and Fusarium crown and root rot of asparagus in replant soils. Plant Dis. 95:960-966.

Gomez-Eyles, J. L., Sizmur, T., Collins, C. D., and Hodson, M. E. 2011. Effects of biochar and the earthworm Eisenia fetida on the bioavailability of polycyclic aromatic hydrocarbons and potentially toxic elements. Environ. Pollut. 159: 616-622.

Grogan, R. G., and Kimble, K. A. 1959. The association of Fusarium wilt and root rot with the asparagus decline and replant problem in California. Phytopathology 49: 122-125. 
Harel, Y. M., Elad, Y., Rav-David, D., Borenstein, M., Shulchani, R., Lew, B., and Graber, E. R. 2012. Biochar mediates systemic response of strawberry to foliar fungal pathogens. Plant Soil 357:245-257.

Hartung, A. C. 1987. Allelopathic potential of asparagus (Asparagus officinalis L.) Ph.D. dissertation, Michigan State University, East Lansing.

Jaiswal, A. K., Elad, Y., Graber, E. R., and Frenkel, O. 2014. Rhizoctonia solani suppression and plant growth promotion in cucumber as affected by biochar pyrolysis temperature feedstock and concentration. Soil Biol. Biochem. 69: 110-118.

Johnson, N. C., Copeland, P. J., Crookston, R. K., and Pleger, F. L. 1992. Mycorrhizae: Possible explanation for yield decline with continuous corn and soybean. Agron. J. 84:387-390.

Komada, H. 1975. Development of a selective medium for quantitative isolation of Fusarium oxysporum from natural soil. Rev. Plant Prot. Res. 8:114-124.

Kormanik, P. P., and McGraw, A. C. 1982. Quantification of vesicular-arbuscular mycorrhizae in plant roots. Pages 37-45 in: Methods and Principles of Mycorrhizal Research. N. C. Schenck, ed. American Phytopathological Society, St. Paul, MN.

LeCroy, C., Masiello, C. A., Rudgers, J. A., Hockaday, W. C., and Silberg, J. J. 2013. Nitrogen biochar and mycorrhizae: Alteration of symbiosis and oxidation of the char surface. Soil Biol. Biochem. 58:248-254.

Lehmann, L. A. 2007. A handful of carbon. Nature 447:143-144.

Liang, B., Lehmann, J., Solomon, D., Kinyangi, J., Grossman, J., O’Neill, B., Skjemstad, J. O., Thies, J., Luizao, F. J., Petersen, J., and Neves, E. G. 2006. Black carbon increases cation exchange capacity in soils. Soil Sci. Soc. Am. J. 70:1719-1730

Matsubara, Y., Hasegawa, N., and Fukui, H. 2002. Incidence of Fusarium root rot in asparagus seedlings infected with arbuscular mycorrhizal fungus as affected by several soil amendments. J. Jpn. Soc. Hortic. Sci. 71: 370-374.

Matsubara, Y., Ohba, N., and Fukui, H. 2001. Effect of arbuscular mycorrhizal fungus infection on the incidence of Fusarium root rot in asparagus seedlings. J. Jpn. Soc. Hortic. Sci. 70:202-206.
Motoki, S., Hattori, T., and Oka, J. 2008. Allelopathy in asparagus. 2: Effect of injection period and concentration on deep placement method of activated charcoal flowable in growing period of asparagus. Acta Hortic. 776:91-104.

Motoki, S., Ozawa, T., Komatsu, K., Tsukada, M., Hattori, T., Komaura, T., and Oka, J. 2002. Allelopathy in Asparagus. 1: Reduction of the allelopathic effect on asparagus by the flowable agents in activated charcoal. Acta Hortic. 381:381-386.

Nigh, E. L. 1990. Stress factors influencing Fusarium infection in asparagus. Acta Hortic. 271:315-322.

Pedersen, C. T., Safir, G. R., Siqueira, J. O., and Parent, S. 1991. Effect of phenolic compounds on asparagus mycorrhiza. Soil Biol. Biochem. 23:491-494.

Phillips, J. M., and Hayman, D. S. 1970. Improved procedures for clearing roots and staining parasitic and vesicular-arbuscular mycorrhizal fungi for rapid assessment of infection. Trans. Br. Mycol. Soc. 55:158-IN16-161-IN18.

Rodriguez-Campos, J., Luc Dendoovenb, L., Alvarez-Bernal, D., and ContrerasRamos, S. M. 2014. Potential of earthworms to accelerate removal of organic contaminants from soil: A review. Appl. Soil Ecol. 79:10-25.

Scheu, S. 2003. Effect of earthworms on plant growth: Patterns and perspectives. Pedobiologia (Jena) 47:846-856.

Tennant, D. 1975. A test of modified line-intersect method for estimating root length. J. Ecol. 63:995-1001.

Wacker, T. L., Safir, G. R., and Stephens, C. T. 1990a. Effects of ferulic acid on Glomus fasciculatum and associated effects on phosphorus uptake and growth of asparagus (Asparagus officinalis L.). J. Chem. Ecol. 16:901-909.

Wacker, T. L., Safir, G. R., and Stephens, C. T. 1990b. Effect of Glomus fasciculatum on the growth of asparagus and the incidence of Fusarium root rot. J. Am. Soc. Hortic. Sci. 115:550-554.

Warnock, D. D., Lehmann, J., Kuyper, T. W., and Rillig, M. C. 2007. Mycorrhizal responses to biochar in soil-Concepts and mechanisms. Plant Soil 300:9-20.

Xu, S., Johnson-Maynard, J. L., and Prather, T. S. 2013. Earthworm density and biomass in relation to plant diversity and soil properties in a Palouse prairie remnant. Appl. Soil Ecol. 72:119-127.

Yang, H. J. 1982. Autotoxicity of Asparagus officinalis L. Am. Soc. Hortic. Sci. 107:860-862. 